\title{
Effect of Temperature and Intake Flow Rate on the Discharge of Treated Water during Whole Year
}

\author{
Muhammad Arshad Ullah*, Muhammad Aslam, Arshad Ali \\ Land Resources research Institute, National Agricultural Research Centre, 45500 Islamabad, Pakistan \\ *Corresponding Author: Muhammad Arshad Ullah, Land Resources research Institute, National \\ Agricultural Research Centre, 45500, Islamabad, Pakistan
}

\begin{abstract}
The discharge from desalination plants is almost entirely water, and .01 percent is salt. Desalination is a process that extracts minerals from saline water. More generally, desalination refers to the removal of salts and minerals from a target substance, as in soil desalination, which is an issue for agriculture. Saltwater is desalinated to produce water suitable for human consumption or irrigation. Due to its energy consumption, desalinating sea water is generally more costly than fresh water from rivers or groundwater, water recycling and water conservation. However, these alternatives are not always available and depletionofreserves is a critical problem worldwide. This experiment resulted that $7 \mathrm{lh}^{-1}$ intake discharge gained the highestposition in attaining the clean water during summer season. So it is resulted from this study that this solar unit desalinized water produced maximumclean water if we adjusted the brackish water @ $7 \mathrm{lh}^{-1}$ intake discharge of untreated water. During winter season due to low temperature, the efficiency of desalinization rate was reduced to 8.8 - 10.4 liters. From this observation, it was cleared that areas having maximum sunshine hours produced the more clean water for drinking purposes.
\end{abstract}

\section{INTRODUCTION}

One of the most invasive tribulations afflicting people all through the world is insufficient way in to clean water and sanitation. Problems with water are anticipated to grow shoddier in the coming decades, with water shortage going on internationally, still in regions presently painstaking water-rich. Addressing these problems calls out for a tremendous amount of research to be conducted to identify forceful new methods of purifying water at lower cost and with less energy, while at the same time minimizing the use of chemicals and impact on the environment. Here we highlight some of the science and technology being developed to improve the disinfection and cleansing of water, as well as efforts to increase water supplies through the safe re-use of wastewater and efficient desalination of sea and brackish water.

Although water is a vital prerequisite for life, freshwater is globally inadequate. Entrance to safe drinking water is collectively known as a basic human right (WHO, 2004). Jagged allocation of freshwater and the ever-increasing human population are causing emerging problems with respect to freshwater availability and accessibility. Gleick (2002) explains the letdown to supply safe drinking water to all people as possibly one of the largest developmental failures of the 20th century. Freshwater resources in South Africa are already almost fully-utilized and under stress (du Plessis et al., 2006). Even though improvements, Sub-Saharan Africa has not met the Millennium Development Goals (MDGs) of reducing the proportion of the population without access to safe drinking water sources by half in 2015 (UNICEF and WHO, 2011).

Water sanctuary is cleared as the consistent accessibility of an adequate amount and feature of water for health, livelihoods and production, together with an acceptable level of water related risks (Grey and Sadoff, 2007). Water scarcity occurs where a divergence exists between the availability of water and the demand for adequate quantities of water for human and environmental uses (Muller et al., 2009).

Solar-powered desalination technologies can be used to treat non-traditional water sources to increase water supplies in rural, arid areas. Water is the basis of life, the origin of human endurance, and the prime material base to guarantee the economy significant development of a country. With increasing global population, the fissure among the supply and demand for water is widening and is reaching such disquieting levels that in some part of the world, it is pretense a menace to human survival ( $\mathrm{Li}$ and Tian, 
2009). The remaining percentage is made up of brackish water, vaguely salty water found as surface water in estuaries and as groundwater in salty aquifers. The need for fresh water is at the apex of the international schema of decisive problems, at least as definitely as climate change. India as a country has $16 \%$ of the world's population and $4 \%$ of its fresh water resources (Abraham and Luthra, 2011).

The fresh water scarcity is a rising setback all over the world because only $1 \%$ of earth's water is freshwater available for human to drink. The US geological survey established that $96.5 \%$ of earth's water is sited in seas and oceans and $1.7 \%$ of earth's water is positioned in the ice caps (Pangarkar et al., 2010).

\section{Experiment Procedure/ Des ign}

The following are the description of solar powered water desalination system AROCELL solar water purifies Australian technology. It only use sun energy, there are no moving parts, no electronics. It is robust and easy to setup, low maintenance and very low in operating cost because the water purifier only need solar energy. The feed water is supplied by gravity or pressure pump CAROCELL direct solar powered desalination technology, working at ambient temperature, heats the input water causing vapors condensation change precluding all bacteria and pathogens, therefore eliminating all water borne diseases Exposure to ultra violet light and extreme heat from solar energy through the advanced composite panels enhances the germ killing process. CAROCELL's increased efficiency $(65 \%$ with peak efficiencies above $80 \%)$ over other solar distillation products $(30-40 \%)$ is a combination of the proprietary materials used to dramatically increase the temperature of the feed water on the solar collector which enhances the evaporation / condensation processes inside the panel. Additionally, this sophisticated geometrical design has easy maintenance, optimum performance and a self-controlling natural convection loop enabling widely superior energy recovery. Under this study 02 solar desalination units were installed NARC, Islamabad-Pakistan.

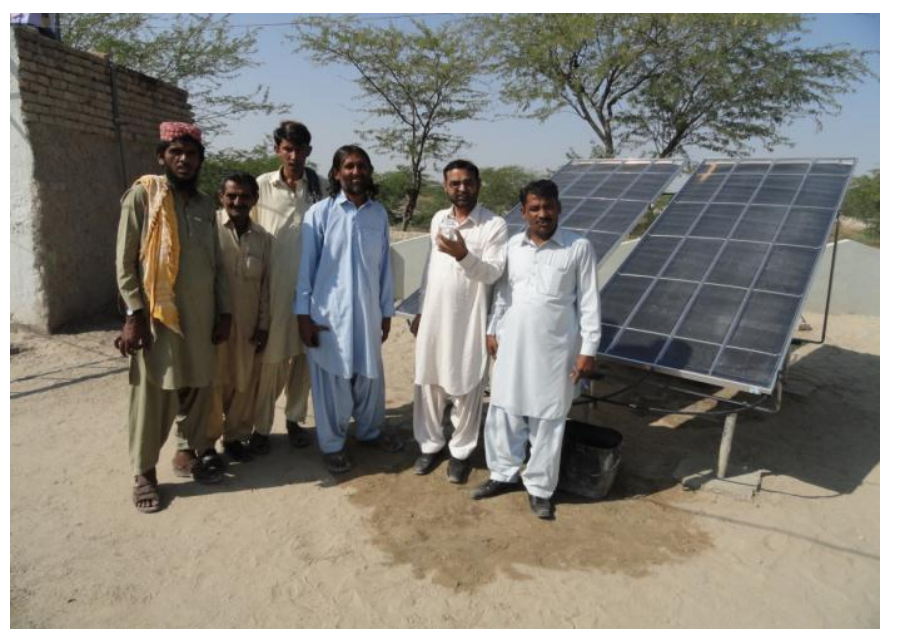

Figure1. Train the farmers for operation and maintenance of solar desalination system

\section{RESULTS AND CONCLUS IONS}

The solar desalination systems were installed in these areas where saline water ranges from $(3,000-$ 20,000) PPM for evaluation and their field performance. The study was conducted to gather data of clean water volume per day along with temperature and solar irradiation. The out flow rate of clean water measured at constant in flow of untreated water along with temperature at 8.0 am to $4 \mathrm{pm}$ daily. It was observed that inflow of untreated water needs to be adjusted along with temperature variation to increase the clean water volume per day.

These types of emitter having discharge $6-8 \mathrm{lh}^{-1}$ discharge were installed at peak temperature months and data indicated that at $7 \mathrm{lh}^{-1}$ intake discharge of untreated water produced 21-22 liters of clean water during eight hours (Table-1).

Table1. Combined effect of temperature and intake flow rate on the discharge of treated water at NARC Islamabad during summer season

\begin{tabular}{|c|c|c|c|c|c|c|}
\hline \multicolumn{2}{|c|}{ Temperature $\left(\mathrm{C}^{0}\right)$} & \multicolumn{3}{|c|}{ Discharge $\left(\mathrm{lh}^{-1}\right)$} & \multirow{2}{*}{$\begin{array}{l}\text { Solar Irradiation } \\
\text { Is lamabad }\left(\mathrm{KWhm}^{-2}\right)\end{array}$} & \multirow{2}{*}{$\begin{array}{l}\text { Treated Water } \\
\left(\text { lday }^{-1}\right)\end{array}$} \\
\hline Min. & Max. & Untreated & Treated & Drain & & \\
\hline \multicolumn{7}{|c|}{ May 2015} \\
\hline 18 & 34 & 6 & 2.40 & 3.60 & 186 & 19.20 \\
\hline & & 7 & 2.65 & 4.35 & 186 & $21.20^{*}$ \\
\hline
\end{tabular}


Effect of Temperature and Intake Flow Rate on the Discharge of Treated Water during Whole Year

\begin{tabular}{|c|c|c|c|c|c|c|}
\hline & & 8 & 2.60 & 5.40 & 186 & 20.80 \\
\hline \multicolumn{7}{|c|}{ June 2015} \\
\hline \multirow[t]{3}{*}{21} & 36 & 6 & 2.75 & 3.25 & 175 & $22.00^{*}$ \\
\hline & & 7 & 2.65 & 4.35 & 175 & 21.20 \\
\hline & & 8 & 2.55 & 5.45 & 175 & 20.40 \\
\hline \multicolumn{7}{|c|}{ July 2015} \\
\hline \multirow[t]{3}{*}{24} & 42.9 & 6 & 2.45 & 3.55 & 163 & 19.60 \\
\hline & & 7 & 2.70 & 4.30 & 163 & $21.60 *$ \\
\hline & & 8 & 2.65 & 5.35 & 163 & 21.20 \\
\hline \multicolumn{7}{|c|}{ August 2015} \\
\hline \multirow[t]{3}{*}{23} & 33 & 6 & 2.50 & 3.50 & 173 & 20.00 \\
\hline & & 7 & 2.80 & 4.20 & 173 & $22.40 *$ \\
\hline & & 8 & 2.65 & 5.35 & 173 & 21.20 \\
\hline \multicolumn{7}{|c|}{ September, 2015} \\
\hline \multirow[t]{3}{*}{18.8} & 33 & 6 & 2.40 & 3.60 & 192 & 19.20 \\
\hline & & 7 & 2.65 & 4.35 & 192 & $21.20 *$ \\
\hline & & 8 & 2.60 & 5.40 & 192 & 20.80 \\
\hline
\end{tabular}

In all the months of summer season $7 \mathrm{lh}^{-1}$ intake discharge gained the highest position in attaining the clean water. So it is resulted from this study that this solar unit desalinized water produced maximum clean water if we adjusted the brackish water @ $7 \mathrm{lh}^{-1}$ intake discharge of untreated water.

The data in table-2 tabulated form showed that the discharge of treated water increased at maximum level under the combined effect of certain temperature and certain intake flow rate of the system. At peak discharge of treated water, the drained water was $2 / 3^{\text {rd }}$ of clean water $(2: 1)$.

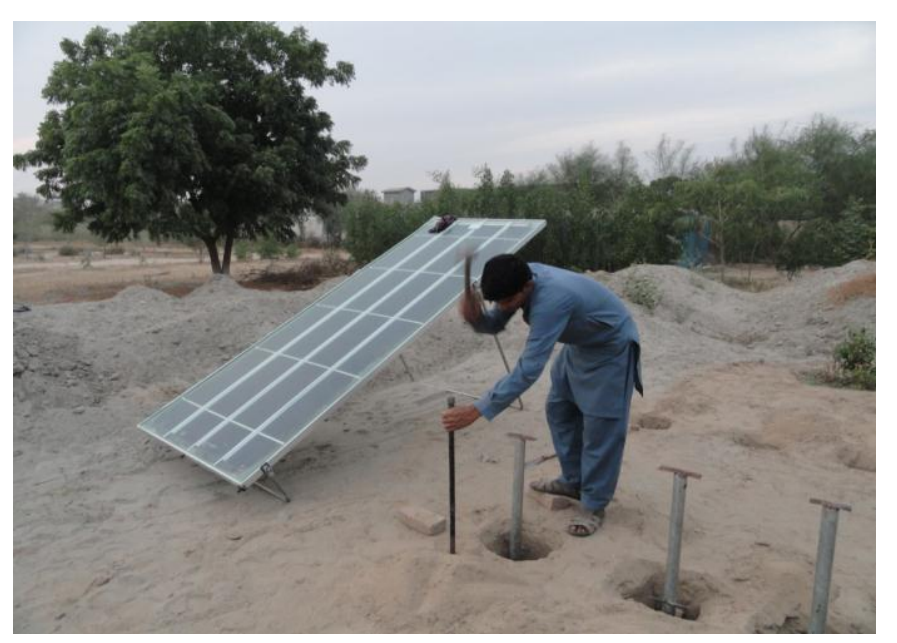

Figure2. Alignment of poles for solar desalination mounted on pole

Three types of dripper 3 to $5 \mathrm{lh}^{-1}$ discharge were installed at low temperature months and data indicated that at $4 \mathrm{lh}^{-1}$ intake discharge of untreated water produced $8.8-10.4$ liters of clean water during 8 hour (Table-2).

Table2. Combined effect of temperature and intake flow rate on the discharge of treated water at NARC Islamabad during winter season

\begin{tabular}{|c|c|c|c|c|c|c|}
\hline \multicolumn{2}{|c|}{ Temperature $\left(\mathrm{C}^{0}\right)$} & \multicolumn{3}{|c|}{ Discharge $\left(\mathrm{lh}^{-1}\right)$} & \multirow{2}{*}{$\begin{array}{l}\text { Solar Irradiation } \\
\text { Is lamabad }\left(\mathrm{KWhm}^{-2}\right)\end{array}$} & \multirow{2}{*}{$\begin{array}{l}\text { Treated Wate1 } \\
\left(\text { lday }^{-1}\right)\end{array}$} \\
\hline Min. & Max. & Untreated & Treated & Drain & & \\
\hline \multicolumn{7}{|c|}{ October, 2015} \\
\hline \multirow[t]{3}{*}{14.9} & 28.8 & 5 & 2.45 & 2.55 & 198 & 19.60 \\
\hline & & 6 & 2.85 & 3.15 & 198 & $22.80 *$ \\
\hline & & 7 & 2.60 & 4.40 & 198 & 20.80 \\
\hline \multicolumn{7}{|c|}{ November, 2015} \\
\hline \multirow[t]{3}{*}{8.8} & 23 & 3 & 0.80 & 2.20 & 172 & 6.80 \\
\hline & & 4 & 1.30 & 2.70 & 172 & $10.40 *$ \\
\hline & & 5 & 0.90 & 4.10 & 172 & 7.20 \\
\hline \multicolumn{7}{|c|}{ December, 2015} \\
\hline \multirow[t]{2}{*}{6.5} & 19 & 3 & 0.70 & 2.30 & 161 & 5.60 \\
\hline & & 4 & 1.10 & 2.90 & 161 & $8.80^{*}$ \\
\hline
\end{tabular}


Effect of Temperature and Intake Flow Rate on the Discharge of Treated Water during Whole Year

\begin{tabular}{|c|c|c|c|c|c|c|}
\hline & & 5 & 0.80 & 4.20 & 161 & 6.40 \\
\hline \multicolumn{7}{|c|}{ January, 2016} \\
\hline \multirow[t]{3}{*}{3.5} & 23 & 3 & 0.8 & 2.20 & 154 & 6.4 \\
\hline & & 4 & 1.1 & 2.90 & 154 & $8.8^{*}$ \\
\hline & & 5 & 0.7 & 4.30 & 154 & 5.6 \\
\hline \multicolumn{7}{|c|}{ February, 2016} \\
\hline \multirow[t]{3}{*}{7.5} & 19.4 & 3 & 0.6 & 2.40 & 164 & 4.8 \\
\hline & & 4 & 1.2 & 2.80 & 164 & $9.6^{*}$ \\
\hline & & 5 & 0.8 & 4.20 & 164 & 6.4 \\
\hline \multicolumn{7}{|c|}{ March, 2016} \\
\hline \multirow[t]{3}{*}{10} & 22 & 3 & 1.1 & 1.90 & 186 & 8.8 \\
\hline & & 4 & 1.3 & 2.70 & 186 & $10.4^{*}$ \\
\hline & & 5 & 1.1 & 3.90 & 186 & 8.8 \\
\hline \multicolumn{7}{|c|}{ April, 2016} \\
\hline \multirow[t]{3}{*}{15.7} & 27.5 & 5 & 2.50 & 3.50 & 174 & 20.0 \\
\hline & & 6 & 2.80 & 3.20 & 174 & $22.4^{*}$ \\
\hline & & 7 & 2.65 & 4.35 & 174 & 21.2 \\
\hline
\end{tabular}

During winter months due to low temperature, the efficiency of desalinization rate was reduced to 8.8 - 10.4 liters. From this observation, it was cleared that areas having maximum sunshine hours produced the more clean water for drinking purposes.

\section{REFERENCES}

[1] Abraham T. and A. Luthra, 2011. Socio-economic and technical assessment of photovoltaic powered membrane desalination processes for India. Desalination. 268(1-3):238- 248.

[2] Du Plessis, J.A., Burger, A.J., Swartz, C.D., Museev, N., 2006. A desalination guide for South African Municipal Engineers. WRC report no. TT 266/06.Water Research Commission, Pretoria, South Africa, $153 \mathrm{pp}$.

[3] Gleick, P.H., 2002. Dirty Water: Estimated Deaths from Water-Related Disease2000-2020. Pacific Institute for Studies in Development, Environment, and Security. Available from: 〈http://www.pacinst.org> [Accessed25/11/2014].

[4] Grey, D. and Sadoff, C.W., 2007. Sink or swim? Water security for growth and development. Water Policy, 9, 545-571.

[5] Li Y. and K. Tian, 2009.Application of vacuum membrane distillation in water treatment. Journal of Sustainable Development. 2(3): 183-186.

[6] Muller, M., Schreiner, B., Smith, L., van Koppen, B., Sally, H., Aliber, M.,Cousins, B., Tapela, B., van der Merwe-Botha, M., Kara, E., Pietersen, K.,2009. Water security in South Africa. Development Planning Division. Working Paper Series No.12, Development Bank South Africa, 40pp.

[7] Pangarkar B. L., P. V. Thorat, S. B. Parjane, and R. M. Abhang, 2010. Performance evaluation of vacuum membrane distillation for desalination by using a flat sheet membrane. Desalination and Water Treatment. 21(1-3):328-334.

[8] Safapour, N. and R. H. Metcalf. 1999. Enhancement of solar water pasteurization with reflectors. Appl. Environ. Microbiol. 65:859-861.

[9] UNICEF and WHO, 2011. Drinking Water Equity, safety and sustainability: Thematic report on drinking water, 64pp.

[10] World Health Organization (WHO), 2004. Guidelines for Drinking-water Quality. Geneva, Switzerland. $1(3) ; 540$.

Citation: Muhammad Arshad Ullah et al., "Effect of Temperature and Intake Flow Rate on the Discharge of Treated Water during Whole Year", International Journal of Research Studies in Biosciences (IJRSB), vol. 6, no. 4, pp. 14-17, 2018. http://dx.doi.org/10.20431/2349-0365.0604003

Copyright: (c) 2018 Authors. This is an open-access article distributed under the terms of the Creative Commons Attribution License, which permits unrestricted use, distribution, and reproduction in any medium, provided the original author and source are credited. 